\title{
Estimating residents' willingness to pay for wetland conservation using contingent valuation: the case of Van Long Ramsar Protected Area, Vietnam
}

\author{
DINH DUC TRUONG \\ Falcuty of Environment, Climate Change and Urban Studies, National Economics University, Vietnam. Giai Phong Street No. 207, Hai Ba Trung \\ District, Hanoi 100000, Vietnam. Tel./fax.: +91-6879768, email: truongdd@neu.edu.vn
}

Manuscript received: 27 August 2021. Revision accepted: 13 October 2021.

\begin{abstract}
Truong DD. 2021. Estimating residents' willingness to pay for wetland conservation using contingent valuation: the case of Van Long Ramsar Protected Area, Vietnam. Biodiversitas 22: 4784-4793. Willingness to pay (WTP) for wetland conservation is an important basis for designing market-based wetland protection strategies and sustainable wetland management. The main objective of this study is to estimate villagers' WTP for wetland conservation in Van Long Wetland Protected Area, Vietnam, and analyze factors influencing WTP. A questionnaire survey based on the dichotomous contingent valuation method (CVM) was conducted at seven communes surrounding Van Long Ramsar Protected Area (VLPA). The results showed that the local people in the studied area appreciate the roles of the wetland in preserving landscape values, supporting livelihoods, and transmitting values to future generations. The value of biodiversity conservation and the value of water filtration and regulation are perceived to a lesser extent in terms of the importance of conservation. Of the 384 respondents, 96\% are WTP for wetland conservation at different levels. With the parametric model, the average value of WTP ranges from 300,000 to VND 328,000 VND /family/year. In the non-parametric model, the average of WTP is from 338,000 to 359,000 $\mathrm{VND/family/year.} \mathrm{The} \mathrm{probability} \mathrm{of} \mathrm{environmental} \mathrm{response'} \mathrm{that} \mathrm{willing} \mathrm{to} \mathrm{pay} \mathrm{for} \mathrm{conservation} \mathrm{is} \mathrm{closely} \mathrm{related} \mathrm{to} \mathrm{their} \mathrm{awareness,}$ family income and payment amount. The results also showed optimistic points that the local people are willing to contribute to improving wetland quality. In a general sense, the results of this study make good contributions to the literature related to WTP for wetland conservation in developing countries.
\end{abstract}

Keywords: conservation, contingent valuation method, sustainable management, values, wetland, willingness to pay

Abbreviations: CVM : Contingent valuation method, VLPA : Van Long Ramsar Protected Area, WTP : willingness to pay

\section{INTRODUCTION}

Wetlands are essential for the existence of human beings. They encompass some of the most productive ecosystems globally and offer ecosystem services that have innumerable advantages (Rani et al. 2019, Kamri et al. 2017). Frescoed habitats range from lakes and rivers and ponds to coastal and maritime regions, such as islands, lagoons, mangroves, and reefs, inundated permanently or periodically. The global water cycle supports primary production and recycling of nutrients and supplies people with fresh water and food. Transport and hydroelectricity are utilized in wetlands. They supply basic materials, genetic resources, and medications. It also contributes to flooded mitigation, coastal protection, and carbon storage and sequestering. For cultural, spiritual values, leisure and inspiration, many are vital (IUCN 2005). However, inland and marine/coastal wetlands have been declining worldwide over the long term. If statistics are available, they have both dropped by roughly $35 \%$, three times the forest loss rate between 1970 and 2015. In contrast, humans, mainly rice and reserves, almost twice as many wetlands as $12 \%$ of wetlands have been produced throughout this period. These increases did not compensate for the loss of natural humidity (Ramsar 2015). The wetland losses in Asia were the highest, but Europe was the worst hit (Shengjie et al. 2017).

Vietnam has a very rich wetland ecosystem distributed throughout the country, extending more than 10 million hectares and including diverse types of wetlands such as lagoons, swamps, estuarine mudflats, forests, coastal mangroves, natural and artificial ponds, and lakes. Despite the high economic, social and ecological importance, many wetland ecosystems in Vietnam have seriously been degraded. In the past 15 years, an estimated 250,000 hectares of coastal mangroves have been lost due to economic growth, urbanization, aquaculture, construction, tourism, and transportation. These causes are driven by the weaknesses in policy, governance and management of wetland resources, in the particular inconsistency of legal system, overlapping of management authorities among agencies, unclear property rights demarcation, lack of financial sources for conservation, and limited scientific data and information to support management (Bubeck et al. 2012; Tyllianakis et al. 2016; Ngoc 2018).

One aspect that needs attention in sustainable management and use of wetlands is information on the economic value of wetlands which can serve as a baseline reference for developing policies and programs (Bhat et al. 2014 ; Castaño-Isaza et al. 2015; Brouwer et al. 2016). 
Nonetheless, in the context of Vietnam, such information is still lacking, fragmented and inconsistent. Vietnam has joined the Ramsar Convention since 1989 and currently has 68 wetland areas across the country that are recognized as having high ecological value. However, decisions on the management and use of wetlands are still mainly administrative and technical, while economic aspects have not been recognized and considered properly (Islam et al. 2017). According to Kamil (2017), decisions on the management and use of wetlands in Vietnam are often based on personal opinions and only take into account the direct benefits that wetlands bring to investors, while the overall benefits that wetlands provide to society are often overlooked or underestimated. Since then, decisions on wetland allocation are often ineffective, not bringing the greatest benefits to the community and society (Barr and Mourato 2014; Ban et al. 2017).

To assess wetland economic values as a foundation for the design of sustainable management in wetlands based on the market, many approaches were employed, one of which is the Contingent Valuation Method (CVM) (Murphy et al. 2018; Nie et al. 2019; Rani et al. 2019). A survey approach inquires about specific preferences, requests, or WTPs for hypothesized situations (Carson 1999). The fundamental objective of the technique is to estimate individual WTPs for changes in environmental quality and quantity (Haab and McConnell 2002). Several studies employing CVM with WTP have been conducted to measure the economic benefit of wetlands protection at recreational places, mangrove forests, and other environmental assets. The societal advantages of biodiversity, for example, in wetlands in south-eastern France along the River Garonne, were calculated by Desaigues and Dumingue (2001). The WTP assessed the restoration program of riparian forests of 70 kilometers utilizing an open and democratic method. Scarpa et al. (2000) performed a survey to assess the impact on the recreational value of wetlands of forming natural reserves. The study is based on 26 Irish kinds of wood on extensive CVM data with around 10,000 visits. Hall and Murray (2002) have utilized the CVM to assess the advantages of good implementation and maintenance of protected areas in Rocky Intertidal habitats in southern California. Several writers (Schutgens et al. 2018 and Murphy et al. 2018, Nie et al. 2019 and Casey and Schuhmann 2019) argue that nations can either establish a new admission charge or increase their existing fees to produce appropriate WTP-based financing for wetland protection. Furthermore, the current literature based on the estimate of WTP has ignored alternate ways of conservation financing (Emerton et al. 2006; Baral et al. 2008; Gelcich et al. 2013; Pedroso and Kungu 2019).

The main purpose of this study is to estimate the willingness to pay by local people for wetland resource conservation in Van Long Ramsar Protected Area (VLPA), Ninh Binh Province, Vietnam. VLPA is recognized as the 9th Ramsar site of Vietnam and the largest preserved wetland area in Northern Vietnam. We use a dichotomous contingent valuation model to estimate people's willingness to pay for wetland conservation. The study first examines the community's perception of wetlands' values and the importance of preserving those values. After estimating the WTP of local residents, some conservation implications are discussed and given in the conclusion.

\section{MATERIALS AND METHODS}

\section{Study area}

This study was conducted in Van Long Ramsar Protected Area (VLPA), Ninh Binh Province, Vietnam (Figure 1). Van Long is the Northern Delta's largest wetland nature reserve and is located in the northeast of Gia Vien District, Ninh Binh Province. In 1999, this place became a nature reserve, recorded in the list of special-use forests in Vietnam, and recognized as a Ramsar site of the world in 2019 (PATA Vietnam 2020). The natural area of the VLPA is about 3,500 ha with the area under the management of the conservation area is 2743 ha, of which the permanent wetland area is more than 400 ha. The Van Long region's borders were freely agreed upon and fully delineated, including the wetland lake area and the particular karst massif beyond. Within the region, a core zone of 902.4 hectares has been identified. There are no people living in the marsh area or on the karst massif hills. Currently, the Van Long Management Board itself is under the direct management of the Provincial Forest Protection Department. The Board is responsible for the overall management of biodiversity conservation and protection of natural resources, law enforcement, and conservation projects.

VLPA is located on the territory of 7 communes in Gia Vien District, Ninh Binh, namely: Gia Hung, Lien Son, Gia Hoa, Gia Van, Gia Lap, Gia Tan, and Gia Thanh. These communes have traditionally relied on paddy rice and fish farming as their key livelihood strategies. Still, the wetland and limestone forest have always offered additional nutrition, medicine, and marketable products. For decades, the residents of Van Long have managed the marsh region. It is a completely exploited resource located in a heavily cultivated, human-dominated landscape. In the early 1990s, the Provincial Authorities carried out the national '327 Program' to the communities in acknowledgment of the watershed services supplied by the limestone forest to the Van Long wetland-a simple payment system based on watershed forest conservation contracts with the community. This developed into the '661Program' (also known as the '5-million Hectares Program') in 1998, which combined forest restoration with a more complex forestland allocation and payment mechanism. Individual families were given specific portions of Van Long area to be protected in exchange for an annual payment per hectare. 


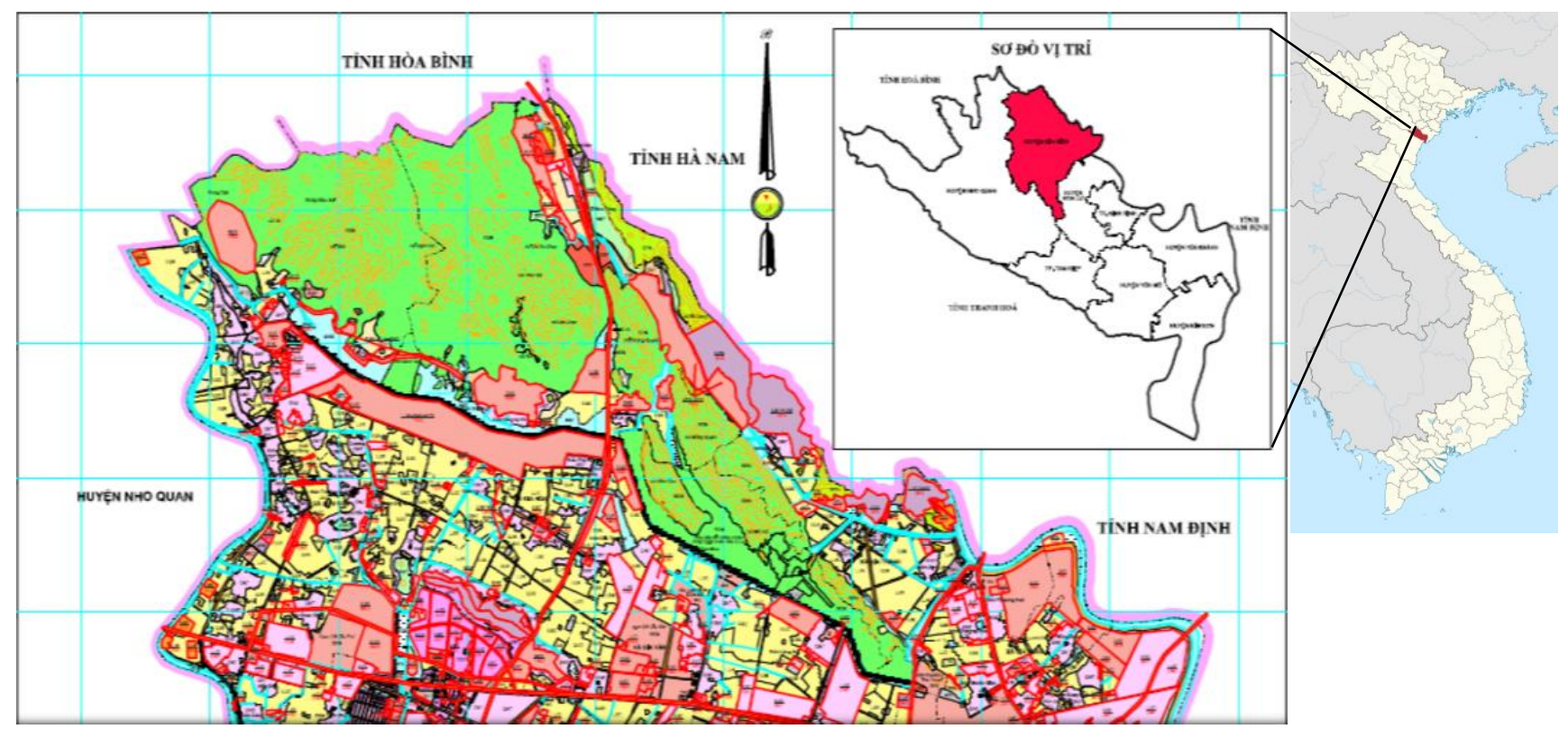

Figure 1. Map of the study location in Van Long Protected Area, Ninh Binh Province, Vietnam. Source: PATA Vietnam (2020)

Evidence of the area's effectiveness in communitybased conservation was highlighted in 1993, when researchers discovered a healthy population of the endemic primate Delacour's langur (Trachypithecus delacouri). This species is exclusively found in Van Long and the adjacent regions of Cuc Phuong National Park and categorized as Critically Endangered by the IUCN with the entire population is estimated to be approximately 200 individuals-making it one of the rarest primate species (ICUN 2005). Results from preliminary biodiversity surveys show that Van Long has 670 species of vascular plants, including 12 species listed in the Red Data Book of Threatened Species in Vietnam, 54 species of fish, 32 species of reptiles, 72 species of birds, 39 species of mammals (including 13 species listed in the Vietnam Red Data Book). Van Long has been in tourism since 1998 and is now a key tourist destination of Vietnam. Tourism developed quickly after the formal establishment of the Reserve. Information about the access and ease to see the globally endangered Delacour's langur made Van Long a popular destination to eco-tourists and increasingly to the domestic market in general.

\section{Economic valuation model}

This study used the dichotomous contingent valuation (CVM) model to assess the willingness of local people to pay for the conservation of wetland values at VLNP. CVM model is widely used in many studies around the world to estimate the non-market values of environmental goods and services, including ecological conservation values (Sudman et al. 1989; Carson 1999; Bateman et al. 2004; Syed et al. 2016; López et al. 2016; Lal et al. 2017). In particular, this study used the Random Utility Model (RUM) for WTP estimation. The model was initiated by Hanemann (1994) and later developed by MacFaden and other authors (Gessa A 2016; La et al. 2017; Pedroso and Kungu 2019).
In the case of CVM, there are two options or alternatives. The equation expresses the indirect utility function of the $j^{\text {th }}$ individual as follow:

$$
u_{i j}=u_{i}\left(y_{j}, Z_{j,}, \varepsilon_{i j}\right)
$$

Where $i=1$ is the state of the environment after improvement (preservation) or the final state, $i=0$ is the current state. The factors affecting the utility of individual $j$ include $y_{j}$ which is the income of household $j, z_{j}$ is the Mdimensional vector including socio-economic characteristics of $\mathrm{HH} j$, and $\varepsilon_{i j}$ is the other dominant factor but not observable. The function $u_{i j}=u_{i}\left(y_{j}, z_{j}, \varepsilon_{i j}\right)$ represents the benefit variation of the environment from the current state to the improved quality state.

More specifically, when environmental quality improves from $\mathrm{q}^{0}$ to $\mathrm{q}^{1}$, then the utility will change from level $u_{0}\left(y_{j}, z_{j}, \varepsilon_{0 j}\right)$ to level $u_{1}\left(y_{j}-t_{j}, z_{j}, \varepsilon_{1 j}\right)$.

Based on this model, individual $j$ has the answer "accept" with a payout $t j$ if the benefits of the improved program minus the costs outweigh the benefits in the initial state: $u_{1}\left(y_{j}-t_{j}, z_{j}, \varepsilon_{1 j}\right)>u_{0}\left(v_{j}, z_{j}, \varepsilon_{0 j}\right)$.

The equation above is the basis for analyzing choice behaviors and can be used for non-parametric estimation but is too broad for parametric models. Two more models are required. First, the functional form of $u_{i j}=u_{i}\left(y_{j}, z_{j}, \varepsilon_{i j}\right)$ must be chosen. Second, the allocation $\varepsilon_{i j}$ needs to be determined. From that, the above benefit equation can be written as:

$$
u_{i}\left(y_{i}, z_{j}, \varepsilon_{i j}\right)=v_{i}\left(y_{j}, v_{j}\right)+\varepsilon_{i j}
$$

The indirect benefit is the sum of the determinable parts and the variable part.

$v_{i}\left(y_{j}, z_{j}\right)=v_{j}\left(y_{j}, z_{j}, q_{i j_{i}}\right)$ with the addition of environmental factors. So, the above equation can be transformed into 


$$
\begin{aligned}
& \operatorname{Pr}\left(\text { yes }_{j}\right)=\operatorname{Pr}\left(v_{1}\left(y_{j}-t_{j}, z_{1}\right)+\varepsilon_{1 j}>v_{0}\left(y_{j}, z_{j}\right)+\varepsilon_{0 j}\right. \\
& \operatorname{Pr}\left(\text { yes }_{j}\right)=1-F_{\varepsilon}\left[-\left(y_{j}-t_{j j}, z_{j}\right)-\left(v_{0}\left(y_{j}, z_{j}\right)\right)\right]
\end{aligned}
$$

The above equation is the starting point for a parametric WTP function of which the most common form is linear. Experimentally, to estimate the parameter WTP function, it is necessary to use the maximum likelihood estimation method. Call the sample size $\mathrm{T}$ and $\mathrm{Ij}=1$ if the answer is yes. The likelihood function becomes:

$\ln L(\alpha, \beta \mid y, z, t)=\sum_{j=1} l_{J} \ln \left[\left(1+e^{-\left(\frac{x_{I}}{\sigma}-\frac{\beta r_{l}}{\sigma}\right)}\right)^{-1}\right]+\left(1-l_{j}\right) \ln \left[1-\left(1+e^{-\left(\frac{x_{I}}{\sigma}-\frac{\beta_{l}}{\sigma}\right)}\right)^{-1}\right]$

for logit form.

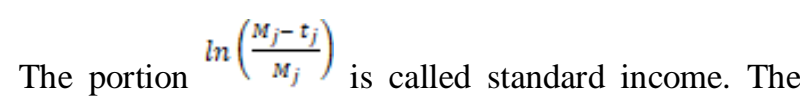
parameter vector $\{\propto / \sigma, \beta / \sigma\}$ can be estimated by running the binary model on the matrix data $\left\{\tilde{g}_{j}, \ln \left(\frac{M_{j}-t_{j}}{M_{j}}\right)\right\}$, thereby allowing the average value of WTP to be calculated:

$$
E_{\varepsilon}\left[W T P_{j}\right]=M_{j}\left[1-\exp \left(-\frac{\alpha}{\beta} z_{j}+\frac{1}{2} \frac{\sigma^{2}}{\beta^{2}}\right)\right]
$$

\section{Data collection}

The study was conducted in 7 communes surrounding the VLPA, including Gia Hung, Lien Son, Gia Hoa, Gia Van, Gia Lap, Gia Tan, and Gia Thanh. Main data were collected in two different ways, namely structured interviews and focus group discussions. Structured interviews were conducted on households as sample units using a questionnaire. Besides, there were also interviews with selected key informants intended to obtain more indepth information about various aspects related to community perceptions and the potential for participation in conservation.

\section{Focus Group Discussion (FDG)}

Two focus group discussions were conducted during December 2020 in the study area to develop the appropriate questionnaire and survey strategy. The first group discussion was conducted with local managers (Gia Vien District), i.e. Gia Vien District People's Committee, District Department of Agriculture and Rural Development, Department of Financial Management Resources and Environment, and VLPA Management Board. The purpose of this group discussion was to provide a forum for managers to discuss issues related to ecological values of VLPA, current status and challenges in the management of the VLPA, pressures and threats to the VLPA, and identifying stakeholders in the management process, as suggested in the previous model (Luu et al. 2018).

The second group discussion was conducted with 14 households in 7 study communes. These families mainly have wetland-based livelihoods. During the discussion, the participants were asked questions related to the perception of the values of wetlands at the VLPA, identifying wetland threats, providing initial payment levels (Bids), and proposing suitable payment methods and reasons for willingness to pay for wetland conservation.

\section{Pre-test}

The pilot survey was conducted in all seven communes in the study area. Thirty-five households participated in the pilot survey and were divided equally among the communes. At the pilot surveys, Bid levels collected in FGD were used. The results were 9 Bid levels: 100,000 VND, 200,000 VND, 300,000 VND, 400,000 VND, 500,000 VND, 600,000 VND, 700,000 VND, 1,000,000 VND and 3,000,000 VND per household per year.

Of the $9 \mathrm{Bid}$ levels that appeared in the focus group discussions and the pilot survey, six were selected in the final questionnaire. According to Awad (2012) and Combes (2018), when using the dichotomous CVM method, the maximum number of Bid levels is eight. This number should be applied only when the Bid distribution range is very large; averaging between 4 and 6 levels should be used. From the survey results in the FDGs and the pilot survey, the cumulative probability of 6 Bid levels was 100,000 VND, 300,000 VND, 500,000 VND, 700,000, and $1,000,000$, which contributed to $91 \%$ of the total choices. Other levels, although some people are willing to pay, were very small. Therefore, the bid levels of 700,000 VND, 1,000,000 VND, and 3,000,000 VND were no longer used.

\section{Sampling}

The household samples were selected in two stages. First, we did a household spatial mapping in each sampled commune. Then, in the second stage, we selected households in each village using simple random sampling based on a list of households provided by seven communes' People Committee. According to the PATA Vietnam (2020), 8,963 households live in 7 studied communes with about 49,295 people (on average, each household has 5.5 people). The study uses the following formula (Van Beukering et al. 2007) to estimate the number of sampled households:

$$
n=\frac{N}{1+N e^{2}}
$$

Where: $\mathrm{n}$ is the sample size, $\mathrm{N}$ is the total number of households in the population, $\mathrm{e}$ is accepted errors.

With $e=0.05$ (the estimated error is $5 \%$ ) and for a total population of 8,963 households, the estimated number of samples to ensure reliability was 384. Thus, 384 households were chosen (4.2\% of total households) for interviews. To ensure the representation, in each commune, researchers selected $4.2 \%$ households for the survey. The total number of research samples is therefore allocated as in Table 1.

\section{Questionnaires}

The questionnaire for evaluation was designed with four main parts. In addition to the introduction stated by investigators regarding the purpose and confidentiality of the information provided, Part 1 provided an overview of the VLPA, its main values and asked the public about their attitudes level, awareness of conservation values on the VLPA, and people's participation in the conservation 
management process. Part 2 included questions about people's willingness to pay for VLNP conservation. With the help of VLPA's Board of management and conservation experts, a conservation scenario was developed and presented to the people. This scenario introduced the features, the most general data on biodiversity values, ecological values (e.g., disaster prevention, groundwater filtration and regulation, biodiversity conservation, absorb $\mathrm{CO} 2$ ), and preserve value for future generations. The villagers were then introduced to the current threats to the VLPA (e.g., agriculture expansion, illegal logging, tourism, commerce). These causes have reduced ecological values and biodiversity in the area, and if not controlled and managed, the trend of decline will continue (Chau 2014). Therefore, conservation, management together with the contribution and participation of stakeholders, including local people, is required to preserve the values of VLPA.

In Part 3, after presenting the conservation scenario, people were asked if they were willing to pay a certain amount of money for conservation. Willingness to pay was randomly selected from 6 Bid levels determined after the pilot survey. The contribution vehicle was a locally conserved environmental fund. Debriefing questions were also designed immediately after the willingness to pay question to identify the reasons for answering "Willing to contribute" and "Not willing to contribute". In addition to examining the impact of illustrations on willingness to pay (WTP), the study also divided the number of interviewees into two groups (182 people each). The first group was introduced and viewed a set of photos ( 5 pieces) about the ecological values of VLPA before answering the WTP questionnaire. The second group was not shown any images before answering the WTP question.

The final part of the questionnaire contained the respondents' demographical questions such as gender, education level, number of people living in the family, and income. The income question divided household income into different ranges for respondents to choose from. This approach proved to be more effective in Vietnam than open-ended questioning (Tran et al. 2008). The mean of the income in the range was then selected for running the regression model about factors affecting the probability of local residents' payment for wetland conservation in the parametric CVM model.

Table 1. Distribution of the sampled households in each commune in Van Long Protected Area, Ninh Binh Province, Vietnam

\begin{tabular}{lcc}
\hline Commune & $\begin{array}{c}\text { Population } \\
(\mathbf{2 0 1 9} \text { census })\end{array}$ & $\begin{array}{c}\text { Sampled } \\
\text { households }\end{array}$ \\
\hline Gia Hung & 7,745 & 60 \\
Gia Hoa & 8,001 & 62 \\
Liên Son & 5,522 & 43 \\
Gia Van & 5,125 & 40 \\
Gia Lap & 7,996 & 63 \\
Gia Tan & 8,208 & 64 \\
Gia Thanh & 6,698 & 52 \\
Total & 49,295 & 384 \\
\hline Note: Compiled from population census data on PATA Vietnam \\
(2020)
\end{tabular}

\section{Willingness to pay to question}

The WTP question was the most critical in the questionnaire. The way the interviewers asked and introduced the question had an impact on people's responses and choices. Therefore, it was necessary to introduce and skillfully make people feel like they are participating in an actual situation with real considerations when deciding to consume an environmental good. This question was expressed in whether people participate in a wetland conservation program in Van Long to preserve its values if they have to pay a certain amount annually (contribution through the local community social Fund - a popular fund in communities in Vietnam).

There are two ways of asking WTP questions: referendum (binary) and open question. According to Carson (1999), Whittington et al. 2012), and Wang et al. 2012), dichotomous questions can best eliminate two types of bias, i.e. starting point and strategy deviations from bringing people into a 'reasonable' corridor of income and economic viability to get the best answer (see explanation below regarding biases). In this way, there were six Bid levels used in dichotomous questions as the result of the pilot survey (i.e. from 100,000 VND to 1,000,000 VND). Then respondents were asked how much is their highest level of WTP (to find the upper bound of WTP).

The final part of the WTP questions was a question about the reasons why the respondents do not want to pay and participate in the conservation program (debriefing question).

\section{Biases and strategy}

According to Harris et al. (2017) and Engel et al. (2008), the most serious difficulty while conducting CVM studies is biased. To eliminate and minimize bias, the study applied some methods and procedures as follows. In terms of strategic bias, to eliminate the strategic attitude of the respondents when answering the questionnaire in the questionnaire and during the interview, the respondents were explained in detail the objective of the interview. They should understand carefully that it is a study on people's attitudes and perceptions about wetlands, contributing to perfecting wetland management solutions for the development of people and communities. Interviewers should not mention the policies used to vent their fear that their answer will lead to bad changes for themselves and their families. In addition, the use of surveyors who are familiar with the locality and close to the people also reduces the attitude of doubt, leading to strategic responses when responding (Garschagen 2013, Chau et al. 2014, Shen et al. 2015).

In term of starting point bias, the dichotomous CVM technique was applied to eliminate this bias. Dichotomous CVM requires a detailed experimental research process, including focus group discussion and field trials to identify and adjust the WTP range, thereby integrating it into the real study. The tested WTP range and binary Yes/No questions reduce starting biases. Information bias and hypothetical bias are minimized by designing user-friendly questionnaires, using visual images, and close-by-local information on biodiversity illustration. Experts and 
scientists collect and comment on this information and explain it carefully and thoroughly to the respondents before answering. In addition, the technique of "cheap talk" (for short) is also used before the WTP question so that the respondents have the feeling that they are participating in a real buying and selling situation (Susilo et al. 2017).

\section{RESULTS AND DISCUSSIONS}

\section{Socio-economic characteristics}

Table 2 summarizes the socio-economic characteristics of the samples. The proportion of men and women in the samples was $62 \%$ male and $38 \%$ female. The average lifetime of households in the villages was 43.2 years. All the respondents $(100 \%)$ were Kinh ethnic. The education level of the respondents in the seven communes studied was relatively low. The number of people who finished secondary school accounted for a large proportion with $75.8 \%$. Primary school students accounted for a relatively small percentage and the rate was similarly low for university/college level (only 2.6\%). No one had a postgraduate degree. According to the survey, the average number of member per household was 5.32 people and this variable was quite similar in all seven communes. The largest family had eight people and the least had two people. The average household income was 92.4 million VND/ household/year with the lowest income level of the household was 58 million VND/household/year and the highest income level was 300 million VND/household/ year.

The majority of the people in the villages are farmers, growing rice and husbandry. Other occupations had a very low proportion with only $2.3 \%$ of households did fishing and gathering firewood at VLPA, and about $2.9 \%$ worked on civil-related jobs such as security or work in cooperatives, district services and authority agencies.

\section{Community's perception on the importance of wetland}

First, the study assessed the perception of the community on the roles of wetlands in the VLPA for community livelihoods. About $68 \%$ of people said that wetland is very important for livelihoods, $18 \%$ of villagers said they are particularly important for livelihood and 14\% of people think the wetland is somewhat important. There were no villagers who thought that the wetland was totally not important for their livelihood. More specifically, incomes generated from wetland activities account for a big proportion of the income of interviewed households. About $46 \%$ of the households reported that wetlands bring about $40-50 \%$ of their total income, $24 \%$ of the households said that income from the wetland accounts for $30-39 \%$ of the entire family income and only $12 \%$ of them think that 20 $29 \%$ of the total income of the whole family comes from wetland-related activities. So, for the people in Van Long, the wetland really plays an important role in their household income.

Table 3 shows the results of the local people's perception of the importance of preserving the values of wetlands in Van Long. For each value of wetland, there are four response levels, namely very important, important, normal, not important. Values of wetlands questioned for conservation include livelihood maintenance value for people, recreational and landscape value, water filtration and regulation value, biodiversity value, and value passed on to future generations.

From the survey results, it can be seen that the local people appreciated the conservation of wetlands to maintain their livelihoods which is indicated by $83.3 \%$ of the respondents thought that conservation is very important and important, and neutral perception accounted for $16.6 \%$, while only $1.12 \%$ thought that wetland conservation is not important for livelihoods. Local people have lived and attached for a long time to the wetlands in Van Long. The average time of living in the locality was 43.2 years per household. Because of that attachment, people appreciated the importance of preserving wetlands for future generations. About $22.9 \%$ of the respondents stated that wetland conservation for future generations is very important, while $28.7 \%$ thought it is important. There are $27.1 \%$ who had a neutral perception, and about $20 \%$ thought it is not important to preserve wetlands for their children and grandchildren.

People's perception of the importance of preserving the above values also varied from commune to commune. However, people were aware of the role of wetlands for their livelihoods and future generations, so they emphasized the important role of preserving these values. Recreational and landscape values were also highly appreciated by the people for the importance of conservation. As many 195/384 people rated preserving this value as important, and $16.2 \%(n=62)$ considered it very important. Over the years, Van Long has become a famous tourist area in Northern Vietnam with thousands of Vietnamese and international tourists visiting. Before the establishment of the Reserve, this was just a wetland for agriculture. However, since 2010, tourism activities have started to prosper and bring income to people and management agencies. Therefore, people appreciate the importance of preserving this value (Trinh et al. 2017).

Table 2. Socio-economic characteristics of the samples in Van Long Protected Area, Ninh Binh Province, Vietnam

\begin{tabular}{lc}
\hline Socio- economic variables & Percentage \\
\hline Gender & \\
$\quad$ Female & $38 \%$ \\
$\quad$ Male & $62 \%$ \\
Age & 45.1 \\
Ethnicity & $100 \%$ \\
$\quad$ Kinh & 43.2 \\
How long has the household lived in the village & \\
(year) & 7.2 \\
Education level of head of household (years of & \\
schooling) & 92.4 \\
Total income of the household per year (million & \\
$\quad$ VND) & \\
Main occupation of the household & $2.3 \%$ \\
$\quad$ Fishing, gathering firewood at VLPA & $3.1 \%$ \\
$\quad$ Hotels, services, tourism, restaurants, cafes & $91.8 \%$ \\
$\quad$ Farmers & $2.9 \%$ \\
$\quad$ Civil servants, office workers (or no job) & 5.32 \\
\hline Number of family members & \\
\hline
\end{tabular}


Table 3. Community's perception on the importance of preserving the values of wetland (\% respondents) in each commune

\begin{tabular}{|c|c|c|c|c|c|c|c|c|}
\hline \multirow{2}{*}{ Wetland value } & \multicolumn{7}{|c|}{ Commune } & \multirow{2}{*}{ Average } \\
\hline & Gia Hung & Gia Hoa & Lien Son & Gia Van & Gia Lap & Gia Tan & Gia Thanh & \\
\hline \multicolumn{9}{|c|}{ Wetland supports local livelihoods } \\
\hline Not important & 2 & 1 & 0 & 3 & 0 & 1 & 1 & 1.14 \\
\hline Neutral & 23 & 18 & 7 & 6 & 22 & 29 & 11 & 16.6 \\
\hline Important & 37 & 43 & 52 & 48 & 41 & 39 & 45 & 43.6 \\
\hline Very important & 38 & 38 & 41 & 43 & 37 & 31 & 43 & 38.7 \\
\hline \multicolumn{9}{|c|}{ Wetland provides landscape beauty and recreational values } \\
\hline Not important & 4 & 10 & 7 & 13 & 4 & 9 & 5 & 7.43 \\
\hline Neutral & 51 & 32 & 29 & 17 & 27 & 32 & 49 & 33.9 \\
\hline Important & 32 & 40 & 43 & 38 & 43 & 45 & 27 & 38.3 \\
\hline Very important & 13 & 18 & 21 & 32 & 26 & 14 & 19 & 20.4 \\
\hline \multicolumn{9}{|c|}{ Wetland charges and fillers water } \\
\hline Not important & 14 & 13 & 23 & 19 & 13 & 15 & 17 & 16.3 \\
\hline Neutral & 55 & 38 & 42 & 62 & 59 & 63 & 51 & 52.9 \\
\hline Important & 25 & 39 & 19 & 14 & 17 & 15 & 19 & 21.1 \\
\hline Very important & 6 & 10 & 16 & 5 & 11 & 7 & 13 & 9.71 \\
\hline \multicolumn{9}{|c|}{ Wetland provides biodiversity } \\
\hline Not important & 12 & 22 & 11 & 15 & 9 & 5 & 4 & 11.1 \\
\hline Neutral & 49 & 32 & 41 & 55 & 47 & 58 & 53 & 47.9 \\
\hline Important & 29 & 32 & 27 & 21 & 28 & 24 & 26 & 26.7 \\
\hline Very important & 10 & 14 & 21 & 9 & 16 & 13 & 17 & 14.3 \\
\hline \multicolumn{9}{|c|}{ Wetland provide benefits for the future generation } \\
\hline Not important & 21 & 32 & 32 & 12 & 25 & 13 & 14 & 21.3 \\
\hline Neutral & 32 & 18 & 21 & 22 & 27 & 32 & 38 & 27.1 \\
\hline Important & 28 & 33 & 17 & 37 & 26 & 31 & 29 & 28.7 \\
\hline Very important & 19 & 17 & 30 & 29 & 22 & 24 & 19 & 22.9 \\
\hline
\end{tabular}

Interestingly, the wetland values on biodiversity conservation and water regulation were less appreciated by the local people. Only $12.1 \%$ considered biodiversity conservation is very important and $16.3 \%$ considered it is important, while more than $65 \%$ stated a neutral perception and about $6.6 \%$ thought it was not important. The function of filtering and regulating groundwater was perceived as very important and important by $7.3 \%$ and $16.2 \%$ by the respondents, respectively. The two values are ecological functions that are less tangible, so the people's perception and assessment of their important role were not high, although they partially perceived the existence of those values.

\section{Estimation of parameters of CVM model}

The study used the Binary Logistic regression model to estimate the expected value of willingness to pay (WTP) of local communities to preserve wetland values at VLPA and to analyze the factors affecting the ability to pay different Bid levels. Of the 384 questionnaires distributed, 12 people did not participate in the conservation program. The debriefing question showed that these 12 households did not participate because they did not trust the local managers (7 votes) and did not believe in the program's effectiveness (5 votes). No household said that conservation is not meaningful to their family. These 12 votes were rejected (according to Carson 1999 as protest), and the final number of the questionnaire for model running was 372 .
There are three models estimated corresponding to 3 different groups of sample data to find the range of expected WTP (Table 4). The breakdown into models also allows the impact on WTP to be considered by illustrating wetland values to respondents before answering questions about WTP.

The empirical model estimates WTP as the probability function of accepting payments for wetland conservation as follow:

\section{$\operatorname{Pr}\left(Y_{\text {eS }}\right)=a_{1}+b_{1} B I D+b_{2}$ EDU $+b_{2}$ MEMBER $+b_{4} I N C O M E+b_{5}$ AGE $+b_{6} S E X$}

Where: the description of variables in the model is shown in Table 5.

The results of running the model with dichotomous logistic regression are presented in Table 6.

In all models, the coefficients of the BID variable are negative and significant at $1 \%$ error. This is consistent with the theory that the higher the BID level, the lower the probability of willingness to pay. Variable INCOME in all models is positive but only significant at $10 \%$ error in model A. Thus, household income affects willingness to pay for wetland conservation but is not so strong in this model. The MEMBER variable is significant only at the $10 \%$ error level in model $\mathrm{B}$. In this model, the number of people in the household affects the willingness to pay for wetland conservation. Households might think that if more people in their families benefited from environmental services, they would pay more for conservation. 
Table 5. Description of variables in the Dichotomous CVM model to estimate willingness to pay (WTP) for wetland conservation

\begin{tabular}{lll}
\hline Variable & Explanation & Coding \\
\hline Pr (Yes) & Probability of willingness to pay a certain amount of Bid to conserve wetland & Yes to pay $=1 ;$ Not to pay $=0$ \\
BID & $\begin{array}{l}\text { The bid level is offered and asked if people are willing to pay that level } \\
\text { (thousands of VND/year). }\end{array}$ & With values 100, 200, 300, 400, 500, \\
& Education level (years of schooling) & 600 \\
EDU & Number of people in the household (person) & Continuous \\
MEMBER & Household income (VND/year) & Continuous \\
INCOME & Age of interviewee (age) & Continuous \\
AGE & Gender & Continuous \\
SEX & & Male $: 1$, Female : 0 \\
\hline
\end{tabular}

Table 4. Description of models of willingness to pay (WTP) of local communities to preserve wetland in Van Long Protected Area, Ninh Binh Province, Vietnam

\begin{tabular}{lll}
\hline Name & Models & Sample size \\
\hline A & General model & 372 \\
B & $\begin{array}{l}\text { Model provided illustrative images } \\
\text { about wetland values }\end{array}$ & 189 \\
C & Model without illustrative images & 183 \\
\hline
\end{tabular}

Table 6. Parametric regression model results to estimate willingness to pay (WTP) for wetland conservation

\begin{tabular}{|c|c|c|c|}
\hline Variables & Model A & Model B & Model C \\
\hline Constant & $\begin{array}{l}13.125 \\
(0.653)\end{array}$ & $\begin{array}{l}12.030 \\
(0.67)\end{array}$ & $\begin{array}{l}12 . .321 \\
(0.78)\end{array}$ \\
\hline BID & $\begin{array}{l}-0.040 * * * \\
(0.006)\end{array}$ & $\begin{array}{l}-0.035 * * * \\
(0.008)\end{array}$ & $\begin{array}{l}-0.041 * * * \\
(0.009)\end{array}$ \\
\hline EDU & $\begin{array}{l}-0.013 \\
(0.059)\end{array}$ & $\begin{array}{l}-0.016 \\
(0.08)\end{array}$ & $\begin{array}{l}0.282 * * * \\
(0.097)\end{array}$ \\
\hline MEMBER & $\begin{array}{l}0.060 \\
(0.045)\end{array}$ & $\begin{array}{l}0.067 * \\
(0.077)\end{array}$ & $\begin{array}{l}-0.017 \\
(0.069)\end{array}$ \\
\hline INCOME & $\begin{array}{l}0.000 * \\
(0.000)\end{array}$ & $\begin{array}{l}0.000 \\
(0.000)\end{array}$ & $\begin{array}{l}0.000 \\
(0.000)\end{array}$ \\
\hline AGE & $\begin{array}{l}0.005 \\
(0.008)\end{array}$ & $\begin{array}{l}-0.009 \\
(0.01)\end{array}$ & $\begin{array}{l}-0.023 \\
(0.015)\end{array}$ \\
\hline SEX & $\begin{array}{l}0.186 \\
(0.191)\end{array}$ & $\begin{array}{l}0.202 \\
(0.271)\end{array}$ & $\begin{array}{l}0.469 \\
(0.344)\end{array}$ \\
\hline-2 Log likelihood & 733.758 & 432.064 & 280.116 \\
\hline \multicolumn{4}{|c|}{$\begin{array}{l}\text { Note: In parentheses is the standard deviation. } * * * \text { : significant a } \\
1 \% \text { error. } * * \text { : significant at the } 5 \% \text { error level. } * \text { : significant at th } \\
10 \% \text { error level }\end{array}$} \\
\hline \multicolumn{4}{|c|}{$\begin{array}{l}\text { Table 7. Estimation of willingness to pay (WTP) levels for } \\
\text { wetland conservation from the parametric regression model }\end{array}$} \\
\hline Model & \multicolumn{3}{|c|}{ WTP (thousand VND/year) } \\
\hline $\mathrm{A}$ & \multicolumn{2}{|l|}{328} & \\
\hline $\mathrm{B}$ & \multicolumn{2}{|l|}{343} & \\
\hline $\mathrm{C}$ & \multicolumn{2}{|l|}{300} & \\
\hline
\end{tabular}

The expected value of WTP for wetland conservation of each parametric model is estimated according to the theoretical formula and presented in Table 7.

$$
E_{\varepsilon}\left[\mathrm{WTP}_{j}\right]=M_{j}\left[1-\exp \left(-\frac{\alpha}{\beta} z_{j}+\frac{1}{2} \frac{\sigma^{2}}{\beta^{2}}\right)\right.
$$

According to the estimation results, the expected value of WTP in the overall model (for all observations) is 328 thousand VND/household/year. The estimation also shows no significant difference in the expected level of WTP between model $\mathrm{B}$ (which provided a picture of wetland values for the people before asking the WTP question) and model C (which did not provide a picture of wetland values). Thus, providing more pictures during the interview does not significantly affect people's willingness to pay.

\section{Estimation of WTP using the non-parametric model}

The study also estimated household WTP levels for wetland conservation at VLPA by the non-parametric model of WTP. The non-parametric model is one that does not take into account the impact of socioeconomic variables on WTP. This model was proposed by Haab and MacConnell (2002) and is calculated based on the average expectation of the BID levels with the weights as the probability levels of accepting each different BIDs. Theoretically, as the BIDs increase, the probability of accepting them tends to decrease and this is also an indication of whether a data set is good or not. In case this does not happen at a certain BID level, it can be overcome through the VAMA pulling technique (Habb and MacConnell 2002). There are also three levels of WTP estimated for the three delineated models, as is the case with the parametric model.

Table 8 and Figure 2 presents the probability distribution of accepting payments for the given Bid levels in the three non-parametric models. The results show that the simple hierarchy is not violated; specifically, the smaller the given Bid level, the higher the willingness to pay the people.

The results of the non-parametric WTP estimation are presented in Table 9, whereby the expected level of WTP ranges from 338 thousand VND/family/year to 359 thousand VND/family/year. In the overall model (A), the expectation of WTP is 352 thousand VND/family/year. 


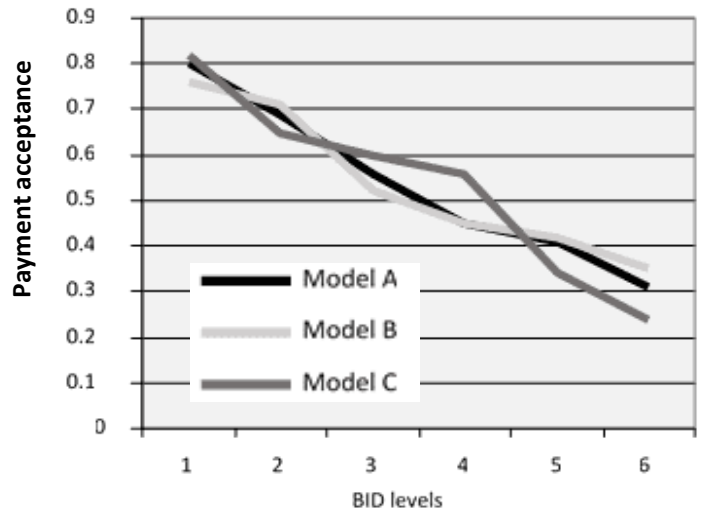

Figure 2. Probability distribution of payment acceptance with given Bid levels

Table 8. Probability distribution of payment acceptance with given Bid levels

\begin{tabular}{lccc}
\hline BID levels & \multicolumn{3}{c}{ Probability to answer "Yes to pay" } \\
\cline { 2 - 4 } (VND 000) & Model A & Model B & Model C \\
\hline 100 & 0.76 & 0.74 & 0.81 \\
200 & 0.66 & 0.70 & 0.64 \\
300 & 0.53 & 0.51 & 0.59 \\
400 & 0.43 & 0.44 & 0.55 \\
500 & 0.39 & 0.41 & 0.34 \\
600 & 0.29 & 0.34 & 0.24 \\
\hline
\end{tabular}

Table 9. Estimation of willingness to pay (WTP) levels for wetland conservation using the non-parametric model

\begin{tabular}{lc}
\hline Model & WTP (thousand VND/year) \\
\hline A & 352 \\
B & 359 \\
C & 338 \\
\hline
\end{tabular}

The result also shows that the mean WTP of the nonparametric model is higher than the WTP of the parametric model. This result is consistent with the findings by Whittington (2012) and Murphy et al. (2018) but inconsistent with the findings by Casey et al. (2019) and Chen (2015). Baral et al. (2008) support this result, but the inconsistent result was revealed in the findings by Lal et al. (2017). Although WTP in the non-parametric model is higher than in the parametric model, in this study, the difference is not large. The same result was also revealed in the studies by Nie et al. (2019) and Pedroso and Kungu (2019).

In conclusion, VLPA is one of the wetlands with the greatest ecological values in Vietnam. Recently, tourism activities in the area have begun to develop, generating income for local people on the one hand and also creating threats to the environment and landscape on the other hand. Over the years, wetlands have provide use and non-use values for local communities. People in Van Long are quite aware of tourism values, livelihood support values and highly appreciate the importance of preserving these values. The bequest value is also given special importance by respondents, who are willing to sacrifice part of their income to conserve wetlands for future generations. Using a binary CVM model with both parameters and nonparameters, the study estimates the WTP of villagers to conserve wetlands in Van Long. The means of WTP ranges from 300 thousand VND/household/year to 359 thousand VND/household/year. This shows that wetland conservation really has economic value to the people. The study also provides implications for mobilizing community resources through appropriate channels to contribute to wetland protection in addition to the resources of management agencies.

\section{ACKNOWLEDGEMENTS}

The author would acknowledge the National Economics University, Hanoi, Vietnam for supporting this study.

\section{REFERENCES}

Awad I. 2012. Using econometric analysis of willingness-to-pay to investigate economic efficiency and equity of domestic water services in the West Bank. J Soc-Econ 41 (5): 485-494. DOI: 10.1016/j.socec.2012.04.025.

Ban N, Davies T, Aguilera S, Brooks C, Cox M, Epstein G, Evans L, Maxwell S, Nenadovic M. 2017. Social and ecological effectiveness of large marine protected areas. Global Environ Ch 43: 82-91. DOI: 10.1016/j.gloenvcha.2017.01.003.

Baral N, Stern M, Bhattarai R. 2008. Contingent valuation of eco-tourism in Annapurna Conservation Area, Nepal: Implication for sustainable park finance and local development. Ecol Econ 66, 218-227. DOI: 10.1016/j.ecolecon.2008.02.004

Barr R, Mourato S. 2014. Investigating fishers' preferences for the design of marine payments for environmental services schemes. Ecol Econ 108: 91-103. DOI: 10.1016/j.ecolecon.2014.09.006.

Bateman IJ, Carson RT, Day B, Hanemann M, Hanleys N, Hett T, JonesLee MJ, Loomes G, Mourato S, Ozdemiroglu E, et al. 2004. Economic valuation with stated preference techniques: A manual. Ecol Econ 50: 155-156. DOI: 10.4337/9781781009727.

Bhat M, McClain M, Ombara D, Kasanga W, Atisa G. 2014. Payment for watershed services in the Mara River Basin: Part I: Institutions and Stakeholder Engagement. DOI: 10.1007/978-3-319-02720-3_31.

Brouwer R, Brouwer S, Eleveld M, Verbraak M, Wagtendonk A, Woerd H. 2016. Public willingness to pay for alternative management regimes of remote marine protected areas in the North Sea. Mar Pol 68: 195-204. DOI: 10.1016/j.marpol.2016.03.001.

Bubeck P, Suu LTT. 2012. Do flood risk perceptions provide useful insights for flood risk management? Findings from central Vietnam. J Flood Risk Manag 5 (4): 295-302. DOI: 10.1111/j.1753318X.2012.01151.x.

Carson RT. 1999. Contingent Valuation: A User's Guide. Department of Economics, UCSD, UC San Diego, CA. DOI: 10.1021/es990728j.

Casey J, Schuhmann P. 2018. PACT or no PACT are tourists willing to contribute to the Protected Areas Conservation Trust in order to enhance marine resource conservation in Belize?. Mar Policy 111: 8 14. DOI: 101. 10.1016/j.marpol.2018.12.002.

Castaño-Isaza J, Newball R, Roach B, Lau WWY. 2015. Valuing beaches to develop payment for ecosystem services schemes in Colombia's Seaflower marine protected area. Ecosyst Serv 11: 22-31. DOI: 10.1016/j.ecoser.2014.10.003

Chau VN, Holland J, Cassells S. 2014. Institutional structures underpinning flood management in Vietnam. Intl J Disaster Risk Reduct 10: 341-348. DOI: 10.1016/j.ijdrr.2014.10.008.

Chau VN. 2014. Assessing the Impacts of Extreme Floods on Agriculture in Vietnam: Quang Nam Case Study. [Dissertation]. Massey University, UK 
Chen WY. 2015. Public willingess-to-pay for conserving urban heritage trees in GuangZhou, South China. Urban For Urban Green 14 (4) 796-805. DOI: 10.1016/j.ufug.2015.07.002.

Combes JL, Hamit-Haggar M, Schwartz S. 2018. A multilevel analysis of the determinants of willingness to pay to prevent environmental pollution across countries. Soc Sci J 55 (3): 284-299. DOI: 10.1016/j.soscij.2018.02.001.

Desaigues B, Ami D. 2001. An estimation of the social benefits of preserving biodiversity. Intl $\mathrm{J}$ Global Environ 1: 73-86. DOI: 10.1504/IJEP.1999.002303.

Emerton L, Bishop J, Thomas L. 2006. Sustainable financing of protected areas: A global review of challenges and options. DOI: 10.2305/IUCN.CH.2005.PAG.13.en.

Engel S, Pagiola S, Wunder S. 2008. Designing payments for environmental services in theory and practice: An overview of the issues. Ecol Econ 65 (4) 663-674. DOI: 10.1016/j.ecolecon.2008.03.011.

Garschagen M. 2013. Resilience and organisational institutionalism from a cross-cultural perspective: an exploration based on urban climate change adaptation in Vietnam. Nat Hazards 67 (1): 25-46. DOI 10.1007/s11069-011-9753-4.

Gelcich S, Amar F, Valdebenito A, Castilla J, Fernandez M, Godoy C, Biggs D. 2013. Financing marine protected areas through visitor fees: Insights from tourists willingness to pay in Chile. Ambio 42: 975 984. DOI: 10.1007/s13280-013-0453-z.

Gessa A, Vivas S, González-Zamora MDM. 2016. Valuing environmental management practices through contingent valuation. A review of recent applications. Intl $J$ Sustain Soc 8 (1): 22-53. DOI: 10.1504/IJSSOC.2016.074949.

Haab TC, McConnell E, 2003. Valuing Environmental and Natura Resources: The Econometrics of Non-market Valuation. Edward Elgar Cheltenham, UK. DOI: 10.4337/9781843765431.

Hall D, Hall J, Murray S. 2002. Contingent valuation of marine protected areas: Southern California Rocky intertidal ecosystems. Nat Resour Model 15 (3): 335-368. DOI: 10.1111/j.1939-7445.2002.tb00093.x.

Hanemann WM. 1994. Valuing the environment through contingent valuation. J Econ Perspect 8 (4): 19-43. DOI: 10.1257/jep.8.4.19.

Harris J, Roach B. 2017. Environmental and Natural Resource Economics: A Contemporary Approach. Routledge, New York. DOI: 10.4324/9781315620190.

Islam GMN, Tai SY, Kusairi MN, Shuib A, Aswani FMN, Senan MKAM, Ahmad A. 2017. Community perspectives of governance for effective management of marine protected areas in Malaysia. Ocean Coast Manag 135: 34-42. DOI: 10.1016/j.ocecoaman.2016.11.001.

IUCN. 2005. Overview of Wetlands Status in Viet Nam Following 15 Years of Ramsar Convention Implementation. Viet Nam Environment Protection Agency. Hanoi, Viet Nam.

Kamil KA, Hailu A, Rogers A, Pandit R. 2017. An assessment of marine protected areas as a marine management strategy in Southeast Asia: A literature review. Ocean Coast Manag 145: 72-81. DOI 10.1016/j.ocecoaman.2017.05.008.

Kamri T, Kasuma J, Fahana N, Harun A. 2017. Willingness to pay for conservation of natural resources in Santubong National Park. Jurnal Manajemen dan Kewirausahaan 19: 16-21. DOI: 10.9744/jmk.19.1.16-21. [Indonesian]

Lal P, Wolde B, Masozera M, Burli P, Alavalapati J, Ranjan A, Montambault J, Banerjee O, Ochuodho T, Mugabo R. 2017. Valuing visitor services and access to protected areas: The case of Nyungwe National Park in Rwanda. Tourism Manag 61: 141-151. DOI:10.1016/j.tourman.2017.01.019.

López-Mosquera N. 2016. Gender differences, theory of planned behavior and willingness to pay. J Environ Psychol 45: 165-175. DOI: 10.1016/j.jenvp.2016.01.006.

Luu C, von Meding J, Kanjanabootra S. 2018. Flood risk management activities in Vietnam: A study of local practice in Quang Nam province. Intl $\mathrm{J}$ Disaster Risk Reduct 28: 776-787. DOI 10.1016/j.ijdrr.2018.02.006.

Murphy S, Campbell I, Drew J. 2018. Examination of tourists' willingness to pay under different conservation scenarios; Evidence from reef manta ray snorkeling in Fiji. PLoS ONE 13, e0198279. DOI: 10.1371/journal.pone.0198279.
Ngoc QTK. 2018. Impacts on the ecosystem and human well-being of the marine protected area in $\mathrm{Cu}$ Lao Cham, Vietnam. Mar Pol 90: 174183. DOI: 10.1016/j.marpol.2017.12.015.

Nie X, Chen Q, Xiao T, Wang H. 2019. Willingness to pay for ecological function regions protection based on a choice experiment method: a case study of the Shiwandashan nature reserve. Quality Quantity 53 (2): 813-829. DOI: 10.1007/s11135-018-0790-x

PATA Vietnam. 2020. Van Long Protected Area. https://web.archive.org/web/20090429145854/http://patavietnam.org/ vn/content/view/696/52/.

Pedroso R, Kungu J. 2019. Tourists' willingness to pay for upstream restoration and conservation measures. J Sustain Tourism 27 (8): 1107-1124. DOI: 10.1080/09669582.2019.1593991.

Ramsar. 2015. The Ramsar Convention's Programme on communication, capacity building, education, participation and awareness (CEPA) 2016-2024. http://www.ramsar.org/sites/default/files/documents/library/ cop12_res09_cepa_e_0.pdf. Referenced 25 January 2016.

Rani S, Ahmed MK, Xiongzhi X, Yuhuan J, Keliang C, Islam M. 2019. Economic valuation and conservation, restoration \& management strategies of Saint Martin's coral island, Bangladesh. Ocean Coast Manag 183: 105024. DOI: 10.1016/j.ocecoaman.2019.105024.

Scarpa R, Chilton S, Hutchinson WG, Buongiorno J. 2000. Valuing the recreational benefits from the creation of nature reserves in Irish forests. Ecol Econ 33: 237-250. DOI: 10.1016/S0921-8009(99)001433.

Schutgens M, Hanson J, Baral N, Ale S. 2018. Visitors' willingness to pay for snow leopard Panthera uncia conservation in the Annapurna Conservation Area, Nepal. Oryx 53: 633-642. DOI: 10.1017/S0030605317001636.

Shen Z, Wakita K, Oishi T, Yagi N, Kurokura H, Blasiak R, Furuya K. 2015. Willingness to pay for ecosystem services of open oceans by choice-based conjoint analysis: A case study of Japanese residents. Ocean Coast Manag 103: 1-8. DOI: 10.1016/j.ocecoaman.2014.10.016.

Shengjie H, Zhenguo N, Hu ZN, Yanfen C, Lifeng L. 2017. Global wetlands: Potential distribution, wetland loss, and status. Sci Tot Environ 586: 319-327. DOI: 10.1016/j.scitotenv.2017.02.001.

Sudman S, Mitchell R, Carson R. 1989. Using surveys to value public goods: The contingent valuation method. Contemp Sociol 20: 243. DOI: $10.2307 / 2072944$

Susilo H, Takahashi Y, Yabe M. 2017. The opportunity cost of labor for valuing mangrove restoration in Mahakam Delta, Indonesia. Sustainability 9 (12): 2169. DOI: $10.3390 / \mathrm{su} 9122169$.

Syed SA, Hoag D, Loomis J. 2016. Is willingness to pay for freshwater quality improvement in Pakistan affected by payment vehicle? Donations, mandatory government payments, or donations to NGO's. Environ Econ Pol Stud 19 (4): 807-818. DOI: 10.1007/s10018-0160178-x.

Tran P, Marincioni F, Shaw R, Sarti M, Van An L. 2008. Flood risk management in Central Vietnam-challenges and potentials. Nat Hazards 46 (1): 119-138, DOI: 10.1007/s11069-007-9186-2.

Trinh VQ, Nauditt A, Ribbe L, Firoz ABM. 2017. Biophysical and Socioeconomic Features of the LUCCi-Project Region: The Vu Gia Thu Bon River Basin. In: Nauditt A, Ribbe L (eds.). Land Use and Climate Change Interactions in Central Vietnam: LUCCi. Springer, Singapore. DOI: 10.1007/978-981-10-2624-9_2.

Tyllianakis E, Skuras D. 2016. The income elasticity of Willingness-ToPay (WTP) revisited: A meta-analysis of studies for restoring Good Ecological Status (GES) of water bodies under the Water Framework Directive (WFD). J Environ Manag 182: 531-541. DOI: 10.1016/j.jenvman.2016.08.012.

Van Beukering P, Brander L, Tompkins E, McKenzie E. 2007. Valuing the Environment in Small Islands-An Environmental Economics Toolkit; Joint Nature Conservation Committee, Peterborough, UK.

Wang PW, Jia JB. 2012. Tourist's willingness to pay for biodiversity conservation and environment protection, Dalai Lake Protected Area: Implications for entrance fee and sustainable management. Ocean Coast Manag 62: 24-33. DOI: 10.1016/j.ocecoaman.2012.03.001.

Whittington D, Pagiola S. 2012. Using contingent valuation in the design of payments for environmental services mechanisms: A review and assessment. World Bank Res Observer 27 (2): 261-287. DOI: $10.2307 / 23262832$ 